\title{
Growth curves of highly inbred lines of fowl and their $F_{1}$ hybrids
}

\author{
Helena KNÍŽETOVÁ, B. KNÍŽE, J. HYÁNEK *, R. ŠILER *, \\ Ludmila HYÁNKOVÁ *, J. PLACHÝ **, Milena VILHELMOVÁ ** \\ Department of Experimental Zoology, Charles University, Viničná 7, 12844 Prague 2, \\ Czechoslovakia \\ * Institute of Animal Production, 25I 61 Prague 10-Uhrínèves \\ ** Institute of Molecular Genetics, ČSAV, Flemingovo 2, 16000 Prague 6
}

\begin{abstract}
Summary
Growth curves based on the Richards function are evaluated for four highly inbred lines of fowl $\left(F_{x}>99.9\right.$ p. 100) and some of their $F_{1}$ hybrids. The largest deviations of the estimated course of growth (maximum : 9.3 p. 100) in terms of live weight occurred before 6 weeks of age; inbred and hybrid groups showed a tendency to deviate in opposite direction as a result of differences in adaptive behaviour during the posthatching period. Another deviation in some groups was an overestimation of the asymptote in relation to the observed values for final weight.

Interline differences occurred in age and weight at the inflection point, the asymptotic weight, the shape of the curve and the parameters of the growth rate. The overall evaluation of lines and hybrid combinations showed that, except for the proportion of asymptotic weight reached at the inflection point, the genetic variation in these parameters was relatively high. Several $F_{1}$ hybrids showed significant heterosis in growth rate and in weight, whereas the shift of the inflection point to an earlier age was mostly insignificant.
\end{abstract}

Key words : Chicken, inbred lines, growth curves, heterosis.

\section{Résumé}

Courbes de croissance de lignées de volailles hautement consanguines et de leurs hybrides $F_{1}$

Des courbes de croissance dérivées de la fonction de Richards ont été établies dans 4 lignées de volailles hautement consanguines $\left(F_{x}>99,9\right.$ p. 100) ainsi que chez certains de leurs croisements $F_{1}$. Les écarts les plus importants en termes de poids vif entre croissance réelle et estimée (maximum 9,3 p. 100) se manifestent jusqu'à un âge de 6 semaines. Les écarts tendent à être de sens opposé chez les individus consanguins et les hybrides suite à des comportements adaptatifs différents au cours de la période postérieure à l'éclosion. Un autre type d'erreur relevé dans certains groupes, est la surestimation de l'asymptote liée aux valeurs observées du poids final.

On a pu mettre en évidence des différences entre lignées pour le poids et l'âge au point d'inflexion, le poids estimé par l'asymptote, la forme de la courbe de croissance et 
les paramètres de vitesse de croissance. L'appréciation générale des lignées et de leurs croisements révèle une variabilité génétique relativement élevée des paramètres à l'exception de la fraction du poids asymptotique atteinte au point d'inflexion. Plusieurs hybrides $F_{1}$ manifestent des effets d'hétérosis significatifs sur la vitesse de croissance et le poids; toutefois, le décalage du point d'inflexion vers un âge plus précoce observé shez les $\mathrm{F}_{1}$, s'avère dans la plupart des cas, non significatif.

Mots clés : Volaille, lignées consanguines, courbe de croissance, hétérosis.

\section{Introduction}

The course of the growth of most mammals and birds, expressed as a weight change in time, is described by an asymmetric, sigmoid-shaped curve with an inflection point where the autoacceleration phase passes into the autoretardation phase. There have been frequent attempts to describe the growth of individuals in a population or in lines by means of some mathematical function. The importance of the derivation and construction of curves is that the information contained at a number of points, given by coordinates of weight and time, can be summarized in several generalizing parameters. The irregular fluctuation of weight caused by random environmental effects is eliminated when the functions are expressed graphically. Another advantage to growth functions is the prediction of animal growth rate, the determination of changes in the shape of the curves in the course of selection, and the application of derived parameters to selection trials. Growth curves can provide information for the estimation of feed requirements. The flexibility of the growth model, i.e. the ability to comprehend different shapes of the curve, is essential in choosing the function.

The three growth functions which have been applied most extensively to animal species are logistic, Gompertz and Bertalanffy curves. RICHARDS (1959) has shown that each of these three functions is a special case in a general family of growth curves which differ primarily in the proportion of final weight at which the inflection point occurs.

A basic requirement for a mathematically derived growth curve is a measure oi the goodness of fit to actual data. The authors consider this essential since it is difficult to construct a curve that agrees completely with the actual course of growth. Most of the functions are sensitive to the frequency and regularity of data on both weight and age. As a rule, a monotonic increase in weight is assumed throughout the period studied. The usual tests for goodness of fit involving residual variance are not appropriate to longitudinal data because of correlated errors among repeated observations over time (FITzhUGH, 1976). Despite this, some authors use these tests, assuming that the source of correlated errors influences residual variances in different cases in a similar way (EISEN et al., 1969 ; TimON \& EISEN, 1969 ; Brown et al., 1976). Another approach to fitting a growth function is to compare observed and predicted body weights at important points of the curve and to evaluate the inter-individual variability and correlations of the analogical parameters estimated by different mathematical functions (FITZHUGH, 1976).

The aim of the present study was to characterize the growth of four highly inbred lines of fowl and their $F_{1}$ hybrids in terms of the Richards function and to analyze 
the differences between estimated growth curve values and observed weights. The genetic aspects of growth and live weight (variability, effects of additivity, dominance, sex linkage, maternal effect, etc.) have been analyzed in two of these lines (C, I) and their hybrids in other studies (Clough \& Cock, 1957 ; Cock \& MorTon, 1963 ; MORTON, 1973).

\section{Material and methods}

Growth was studied in chickens of four highly inbred lines $\left(F_{x}>99.9\right.$ p. 100) $C$, I (Iowa), W and M (Minor) which have been characterized in detail by FestiNG (1979). Lines C, I and W were derived from White Leghorns by sib mating at the Northern Poultry Breeding Station, Reasehealt, Cheshire, starting in 1932. Line C was developed from a pair of WL purchased from a commercial breeder. Line I was obtained from a group of three males and five females inbred WL imported from Iowa State University in 1937. Line W originated as a British commercial line WL; a colour variant with barring pattern, that appeared in 1941, was subsequently fixed. Finally, line M was established in 1956 at the Czechoslovak Academy of Sciences from Black Minor and maintained by brother $\times$ sister mating. Of the $\mathrm{F}_{1}$ hybrids, groups $\mathrm{I} \times \mathrm{C}, \mathrm{I} \times \mathrm{W}$, $\mathbf{I} \times \mathbf{M}, \mathbf{W} \times \mathbf{C}, \mathbf{M} \times \mathbf{C}$ and $\mathbf{M} \times \mathbf{W}$ (sire line $\times$ mother line) are represented in the present trial. With regard to demand on the same hatching, the numbers of birds in inbred lines and hybrids were low (C - 55, I - 23, W - 26 and $M-25)$. In total, the $F_{1}$ hybrids were represented by 79 cocks and 77 hens.

All the chicks were reared in litter floor pens in an environmentally controlled room. The diet contained 19.3 p. 100 protein and $11.82 \mathrm{MJ}(2823 \mathrm{kcal}) \mathrm{ME} / \mathrm{kg}$. Both feed and water were provided ad libitum. Until the age of 10 weeks the chickens were weighed at 7-day intervals and, in the subsequent period, at intervals of 2 weeks (up to 32 weeks in hybrids and 36 weeks in lines).

The records up to the end of the studied period were not used in some cases to calculate the growth curve parameters of pullets and we only used data up to the first decline of live weight because applying mathematical growth functions supposes a monotonic live weight increase. Since laying began in most groups before we had finished weighing the birds, usually a decrease of live weight is seen.

The changes in the weight of each individual during postnatal growth were expressed by the four-parameter Richards function (RICHARDS, 1959) :

$$
\begin{aligned}
& y_{t}=A\left(1 \pm b e^{-k t}\right)^{-\frac{1}{n}} \text { for } n>-1, n \neq 0, A, k>0 \\
& \text { if } n<0 \text { (function of type } 3) \quad y_{t}=A\left(1-b e^{-k t}\right)^{-\frac{1}{n}} \\
& \text { if } n>0 \text { (function of type 1) } y_{t}=A /\left(1+b e^{-k t}\right)^{\frac{1}{n}}
\end{aligned}
$$

The parameters, estimated using the generalized least-squares method, are the following : 
$y_{t}$ - body weight (grams) and age $t$ (days),

A - asymptotic value of size as $t \rightarrow \infty$; generally interpreted as average size at maturity independent of short-term fluctuation of size in response to extraneous environmental effects, ficance,

b - integration constant; time scale parameter of no specific biological signi-

$\mathbf{k}$ - rate at which a logarithmic function of degree of maturity in body weight changes linealy per unit of time; this rate estimates the maturation rate of the curve (i.e. the relative rate at which $\mathrm{A}$ is reached),

$\mathrm{n}$ - shape parameter determining the position of the inflection point of the curve. In the original Richards function it was designated as $m(m=n+1)$ and by other authors as $M\left(M=\frac{-1}{n}\right)$, and established the degree of maturity in body weight at the point of inflection.

If $\mathrm{n}=1$, the function is logistic $\left(\mathrm{y}^{*} / \mathrm{A}=0.5\right)$. Cases in which $\mathrm{n} \rightarrow 0\left(\mathrm{y}^{*} / \mathbf{A}=\right.$ $0.368)$ correspond to the Gompertz function and those where $n=-0,33\left(\mathrm{y}^{*} / \mathrm{A}=\right.$ 0.296) correspond to the Bertalanffy function.

Weight $\left(\mathrm{y}^{*}\right)$ and age $\left(\mathrm{t}^{*}\right)$ at the inflection point were calculated from the parameters of the curve. The inflection point represents mathematically the time at which the second derivative of the growth curve changes from positive to negative :

$$
\mathrm{y}^{*}=\mathrm{A} / \sqrt[\mathrm{n}+1]{\mathrm{n}+\mathrm{t}} \mathrm{t}^{*}=-\frac{1}{\mathrm{k}} \ln \left|\frac{\mathrm{n}}{\mathrm{b}}\right|
$$

Further derived parameters included the average absolute growth rate $\mathrm{v}(\mathrm{g} / \mathrm{day})$ and maximal absolute growth rate $\mathrm{v}^{*}(\mathrm{~g} /$ day at which the inflection point was reached) :

$$
\mathrm{v}=\mathrm{Ak} / 2(\mathrm{n}+2) \quad \mathrm{v}^{*}=\mathrm{y}^{*} \frac{\mathrm{k}}{\mathrm{n}+1}
$$

The coefficient of determination $\mathrm{R}^{2}$ was calculated for each individual growth curve :

$$
R^{2}=1-\frac{\sum\left(y_{i}-y_{i}^{T}\right)^{2}}{\sum\left(y_{i}-\bar{y}\right)^{2}} \text { where } \begin{aligned}
& y_{i} \text { - observed weight } \\
& y_{i}^{T} \text { - estimated weight }
\end{aligned}
$$

The coefficient of determination and the percentage deviations of the observed values of weight at individual points of the curve characterized the accuracy of curve fit to the observed course of growth. Animals with an $\mathrm{R}^{2}<0,99$ were eliminated from the overall analysis. The parameters of the curves of the inbred lines and hybrid 
combinations were evaluated by analysis of variance; the differences were verified by the t-test.

The $F_{1}$ hybrids were compared with the parent lines and deviations from midparent values were tested; the significance was evaluated using WEBER's (1972) formula :

$$
\hat{\psi}=2 \bar{x}_{\mathrm{AB}}-\overline{\mathrm{x}}_{\mathrm{A}}-\overline{\mathrm{x}}_{\mathrm{B}} \quad \mathrm{t}=\frac{\dot{\psi}}{\sqrt{\mathrm{s}_{\hat{\psi}}^{2}}}
$$

In the many cases where the hybrids exceeded the parent line with the higher parameter values, i.e. $F_{1}>\max .\left(P_{1}, P_{2}\right)$ the differences were verified by the $t$-test.

\section{Results and discussion}

\section{A. The course of growth}

Changes in the weight of chickens in individual lines and in hybrid combinations during postnatal development are illustrated by figure 1 . The limited number of individuals in each group does not allow a reliable evaluation of differences in the variability of lines and hybrids. Nevertheless, the variability of weight expressed by the coefficients of variability (tabl. 1) seemed to increase to the age of 6-10 weeks and then markedly decrease. The expected trend to lower variability in the weight of hybrids compared with parent lines seemed to be manifested in older age classes. Differences in body weight between the sexes steadily increased throughout the course of growth. At maturity, the cocks of individual groups reached 120 to 140 p. 100 of the weight of the hens.

A comparison of $F_{1}$ hybrids of both sexes with the parent lines showed a marked heterosis effect $\left(F_{1}>\max . P_{1}, P_{2}\right)$ in weight at 2 weeks of age. This might be explained as a better adaptation of the hybrids in the period after hatching. However, as seen from the percentage deviations from mid-parent values (tabl. 2), the relative positions of different hybrids became apparent with further development, particularly in terms of dependence on the cross combination.

\section{B. Fit of the growth function}

The difficulties of fitting the generalized Richards function arise mainly from the high correlation $\left(r_{\mathrm{r}}=+0.90\right)$ between the constant $k$ and the shape parameter of the curve (Timon \& Eisen, 1969 ; Rutledge et al., 1972). In our trials the goodness of fit of the growth curves was measured by using the coefficient of determination $\left(R^{2}\right)$, by evaluation of the differences between the estimated asymptote (A) and the highest weight $\left(\mathbf{A}^{\prime}\right)$ observed in the period studied, and by comparing the percentage deviations of observed weight from the theoretically determined values at different points of the curve. 


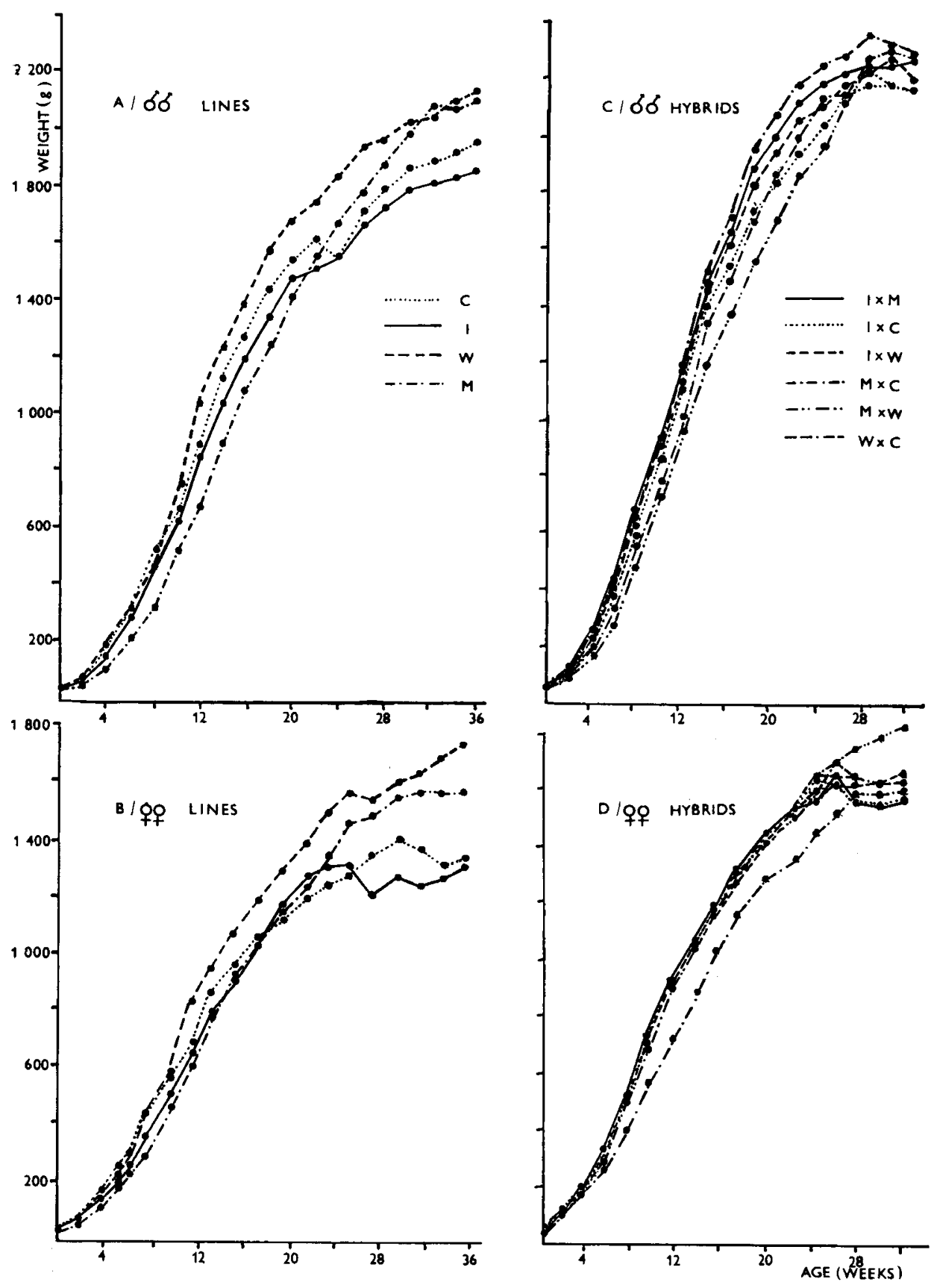

FIG. 1

Course of growth of cockerels and pullets of inbred lines and $F_{1}$ hybrids. Déroulement de la croissance des coqs et des poules des lignées consanguines et des hybrides $F_{1}$. 


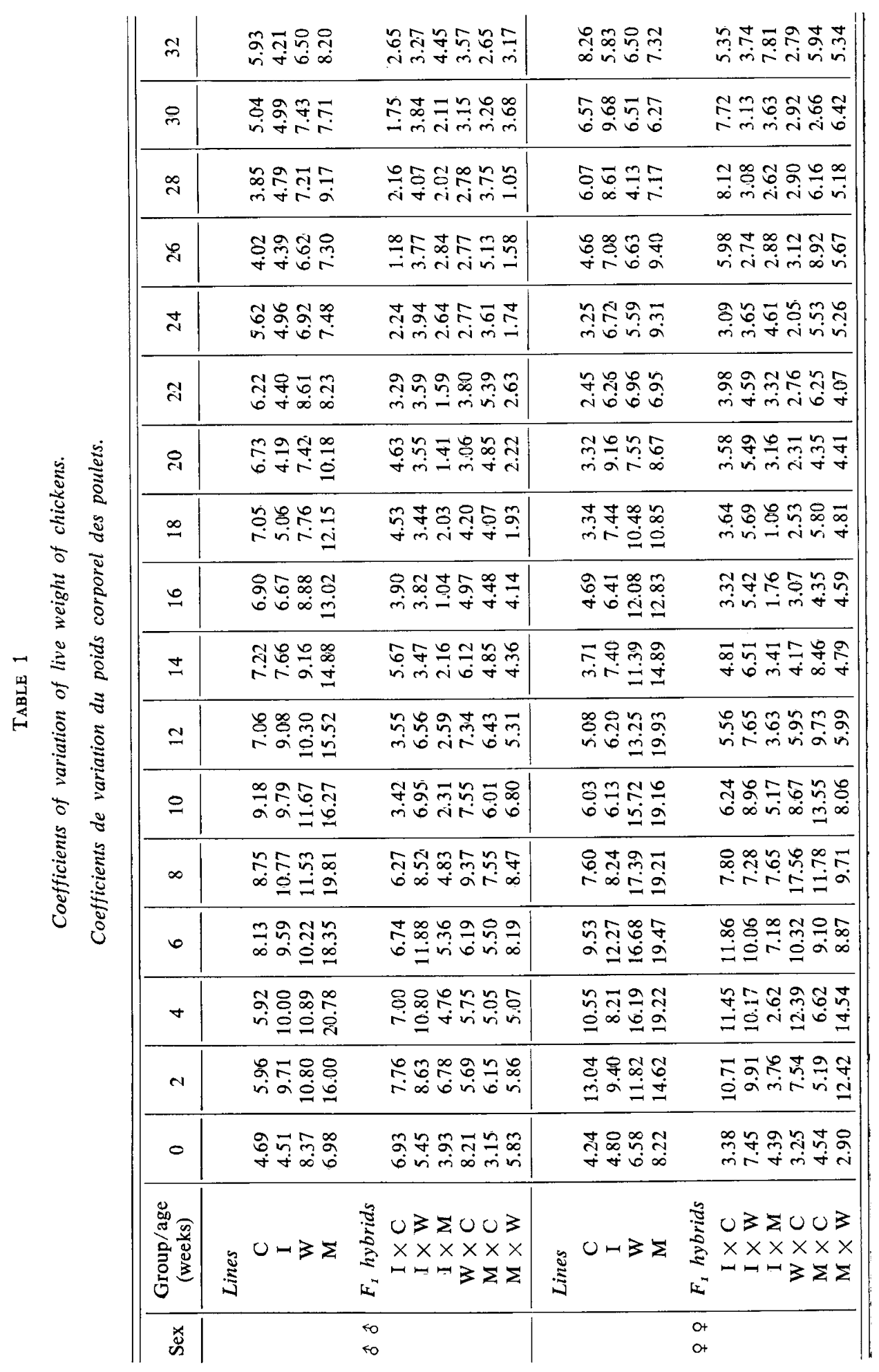




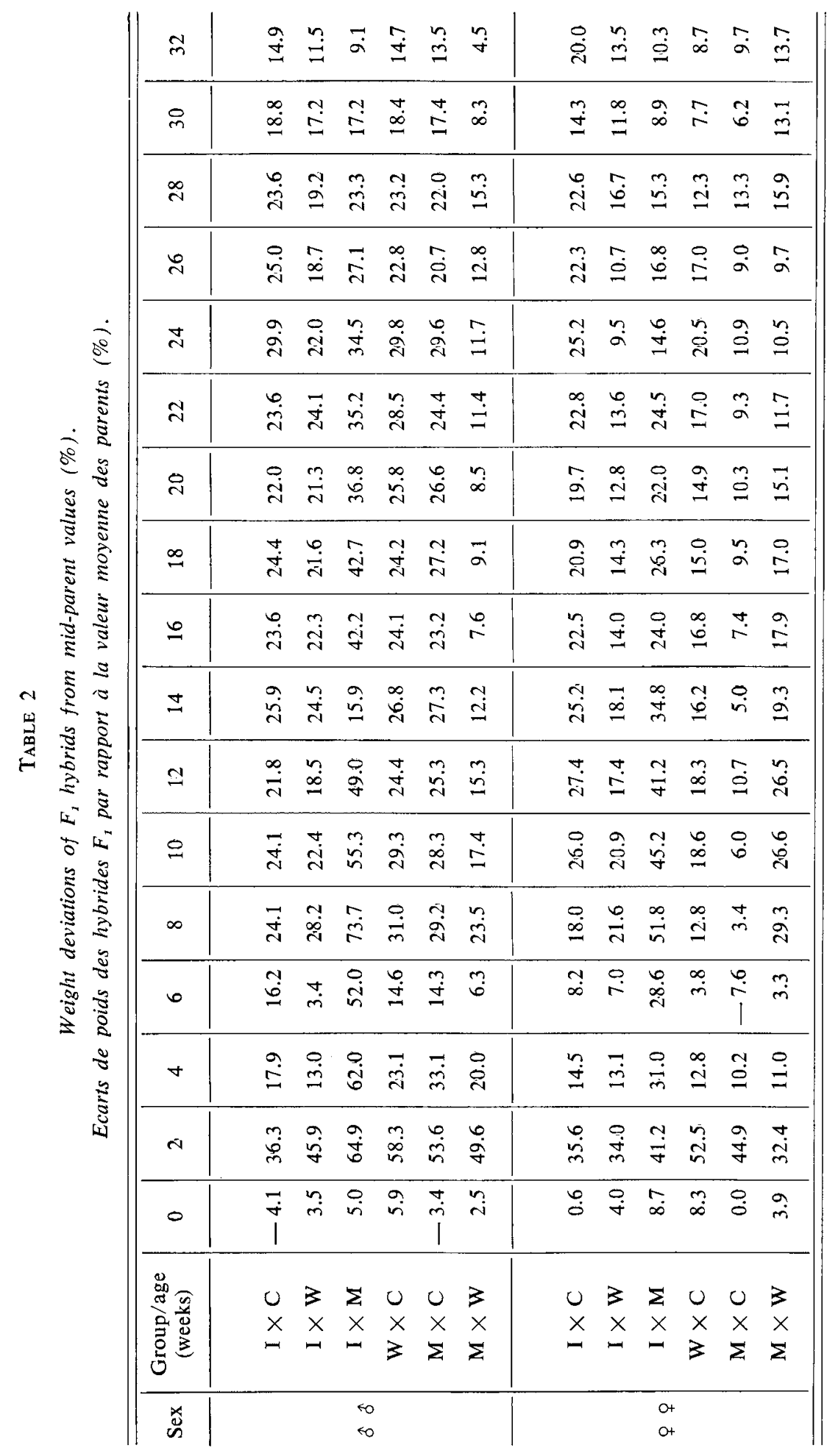


With respect to the determination coefficient of individual growth curves $\left(R^{2}>\right.$ 0.99 ), we eliminated a higher number of individuals in inbred lines (6.9 p. 100) than in $F_{1}$ hybrids (1.3 p. 100) from the overall analysis. Kidwell et al. (1969) also report that, in applying the Gompertz function to mice, more inbred animals (3.9 p. 100) than hybrids $(0.2$ p. 100$)$ had to be eliminated. One explanation of these results might be the higher sensitivity of inbred birds to randomly changing environmental conditions and also a higher fluctuation of gains during growth (including temporary stagnation or a decrease of live weight).

An important criterion of the accuracy of the estimated curve parameters is a comparison of the asymptote (A) with the highest observed weight $\left(\mathrm{A}^{\prime}\right)$. The data in table 3 show that percentage deviations from the estimated asymptote were usually higher in hybrid combinations than in inbred lines. A comparison of the different groups indicates that the growth curve of cockerels of inbred lines corresponds to the type 3 function $(n<0)$ in only 5 p. 100 of the cases, whereas it corresponds in hybrid combinations in 44 p. 100 of the individuals. A similar situation was found in pullets (18 p. 100 vs. 49 p. 100), but the case of the Iowa line was special. When weight data were used up to the age of 30 weeks (practically up to the termination of growth) to calculate parameters of the curve, the asymptote was overestimated by 10.4 p. 100 . When all the data were used (i.e. up to 36 weeks; the Iowa line is designated by $I^{\prime}$ ), the estimate of $A$ was improved (the difference between $A$ and $A^{\prime}$ was reduced to 3.7 p. 100) but the determination coefficient was much lower $(0.9860$ vs. 0.9957). This means that the theoretical curve did not fit the observed course of growth (fig. 2).

The main reason for the overestimation of asymptotic weight is the overall character of growth in the studied period as expressed by shape parameter $\mathrm{n}$. This parameter, which estimates the position of the inflection point of the curve, also reflects the grade of sigmoid curving. In growth curves with less sigmoid curving, i.e. with lower values of $n(n<0)$, the estimated value of the asymptote is higher. In spite of that, A did not correspond to the highest observed live weight; in the case of a given estimated $n$, the theoretical growth curve gave the best fit for the observed course of growth.

The next factor influencing the estimation of $\mathrm{A}$ are irregularities in weight when the animals neared maturity. The lines were considerably different in the age at sexual maturity. The pullets of the hybrid groups started laying eggs substantially earlier (tabl. 4). The observed weight of cocks in some hybrid combinations fluctuated in the final phase of growth due to their social behaviour. In addition to this, we noted that the well-known difficulty in estimating final weight is to determine the proportion of physiologically unessential fat (LILJEDAHL, 1970 and others).

A comparison of the differences between estimated and observed weight in chicks of inbred lines and hybrid combinations during the studied period showed that the greatest deviations were recorded in the initial stage of postnatal growth, i.e. up to about 6 weeks of age (fig. 3$)$. The differences are comparatively low $(\sim 1.5$ p. 100) in the region of the inflection point and this trend was the same up to the end of the period studied. In the post-inflection part of the curve, the average deviations of the curve did not usually exceed \pm 4 p. 100 . In this connection, it should be noted that deviations of observed weights ranging between -7.1 and +5.2 p. 100 were also found in mice after the goodness of fit of the Gompertz function had been analyzed (LAIRD \& HoWARD, 1967). 


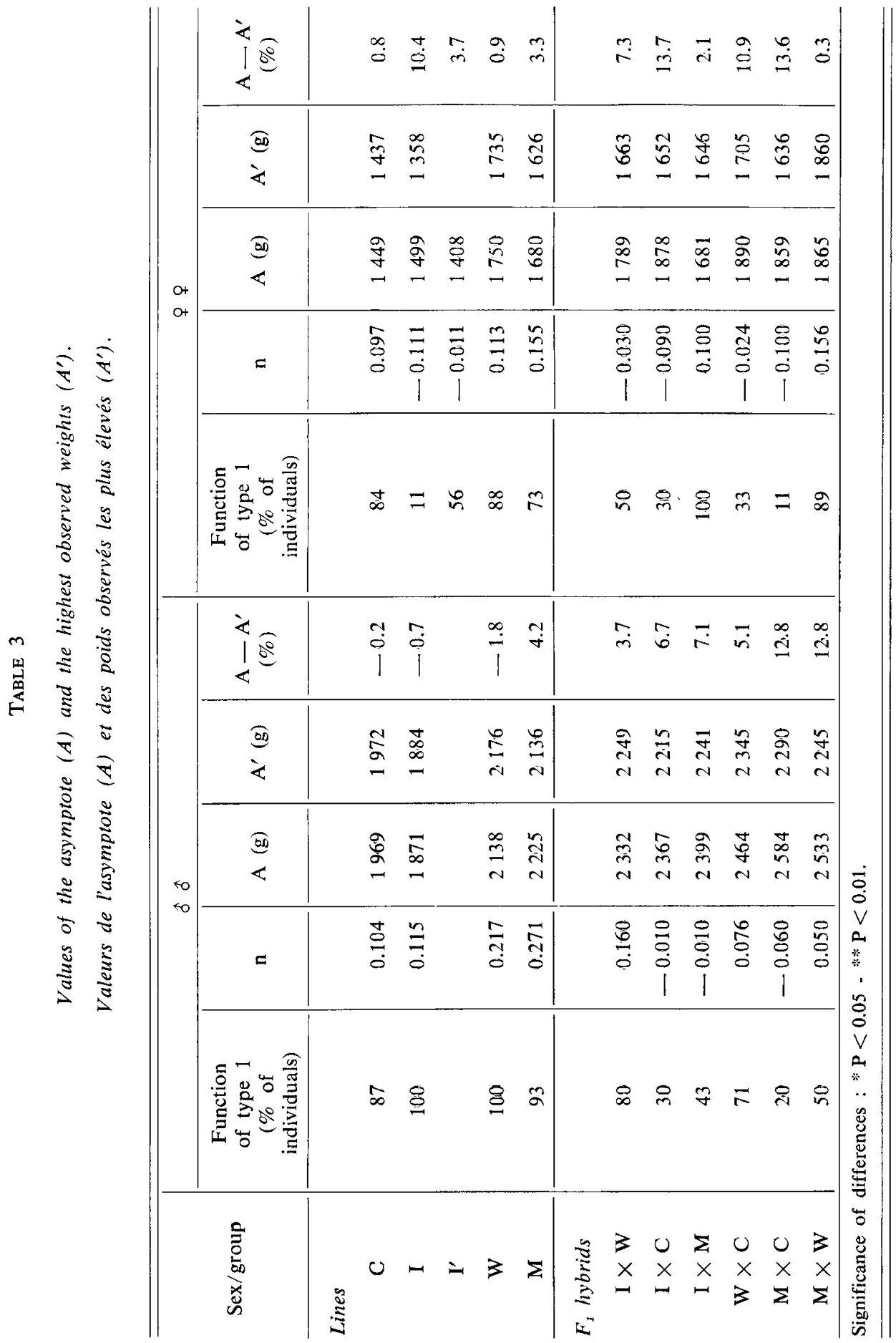




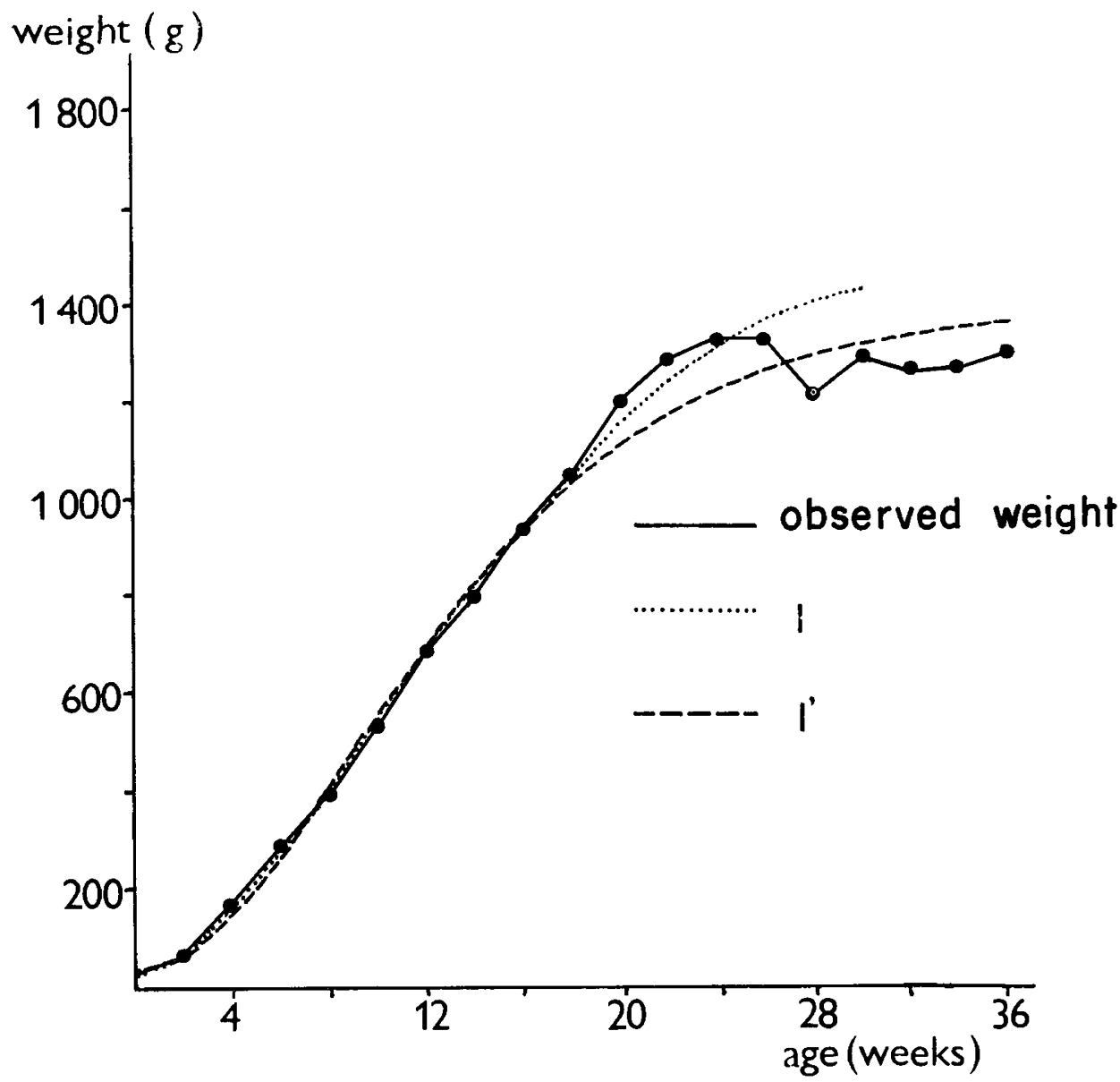

FIG. 2

Growth curves of pullets of the Iowa line depending on the number of weight data used for estimation.

Courbes de croissance des poules de la lignée lowa établies suivant différents échantillons de poids.

In evaluating of percentage deviations of observed weights from fitted values it should be emphasized that conspicuous differences existed between inbred lines and hybrid combinations $(\mathrm{P}<0.01, \mathrm{P}<0.05)$ particularly in the initial phases of growth. In 2-week old hybrids of both sexes the theoretical values were significantly underestimated, whereas at 6 weeks of age they were overestimated. A reverse trend was found in inbred chickens. The pronounced positive deviation of the observed weights of 2-week old hybrids seemed to be related to heterosis effect during this period (tabl. 2). The negative deviation of inbred chickens could be attributed to their low ability to adapt to the conditions of postnatal life. The opposite trend (shown by deviations at the age of 6 weeks) may reflect the compensation of differences arising after hatching. 


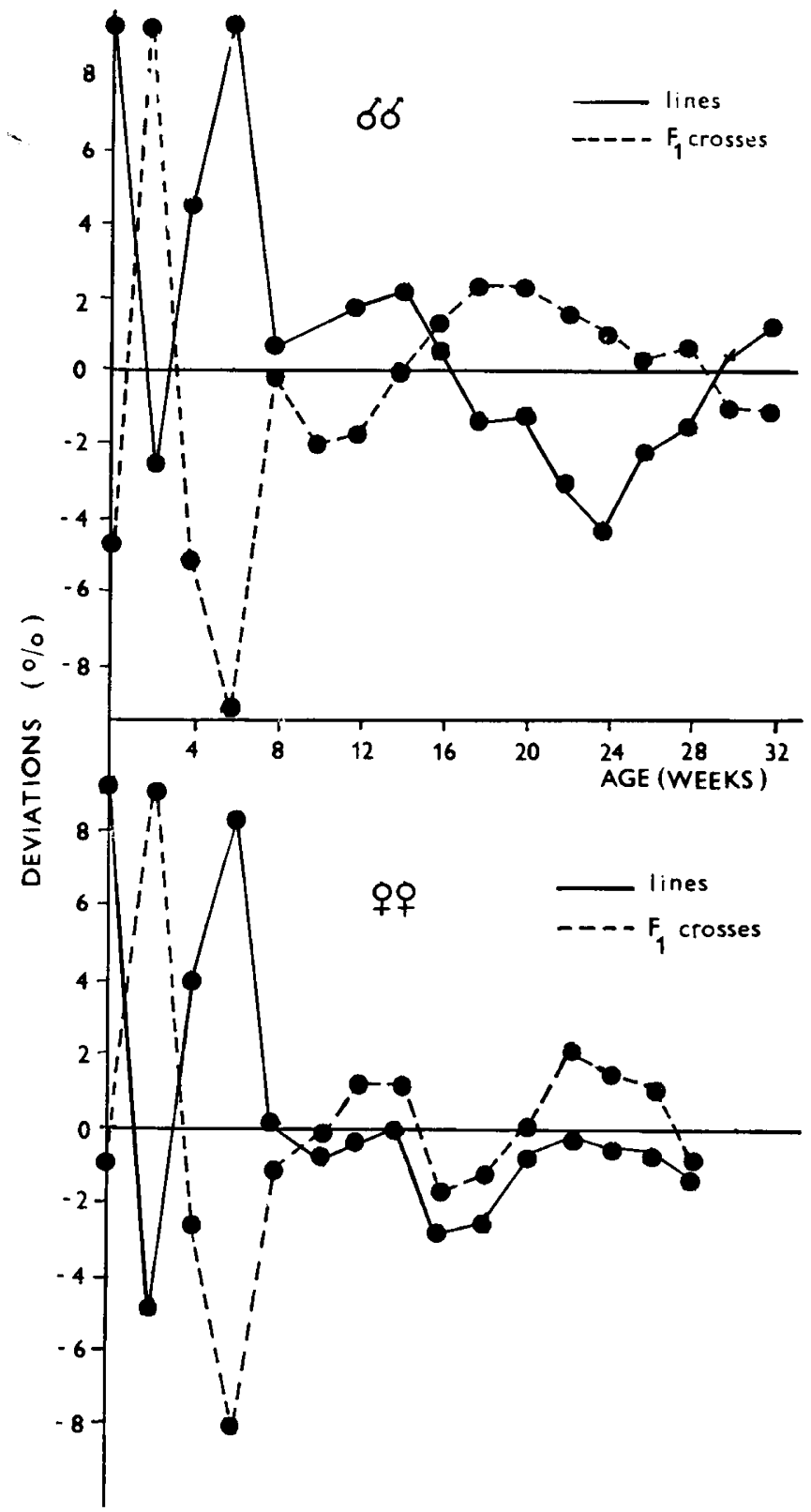

FIG. 3

Mean deviations of actual weights from theoretical values estimated by mathematical function ( $p .100)$.

Ecarts moyens de poids réel par rapport aux valeurs prévues par la fonction mathématique ( $p .100)$. 
TABLE 4

Sexual maturity of pullets.

Maturité sexuelle des poules.

\begin{tabular}{|c|c|c|c|c|c|c|c|}
\hline Group & $\bar{X}$ (days) & S.E. & $\begin{array}{l}\text { C.V. } \\
(\%)\end{array}$ & Group & $\overline{\mathrm{X}}$ (days) & S.E. & $\begin{array}{l}\text { C.V. } \\
(\%)\end{array}$ \\
\hline C & 207.9 & 2.54 & 5.9 & $\mathrm{I} \times \mathrm{C}$ & 166.5 & 0.87 & 1.4 \\
\hline I & 196.7 & 4.01 & 7.9 & $\mathrm{I} \times \mathrm{W}$ & 171.0 & 1.93 & 3.6 \\
\hline W & 268.9 & 6.41 & 8.3 & $\mathbf{I} \times \mathbf{M}$ & 166.3 & 1.42 & 2.4 \\
\hline \multirow[t]{3}{*}{$\mathbf{M}$} & 251.8 & 5.10 & 6.4 & $\mathrm{~W} \times \mathrm{C}$ & 180.4 & 1.21 & 1.9 \\
\hline & & & & $\mathbf{M} \times \mathbf{C}$ & 184.3 & 3.15 & 5.4 \\
\hline & & & & $M \times W$ & 183.8 & 2.93 & 5.0 \\
\hline
\end{tabular}

\section{Parameters of the growth curves of inbred lines and hybrid combinations}

The high degree of inbreeding $\left(F_{x}>99.9\right.$ p. 100) suggests that the intraline variability in growth curve parameters could be ascribed mainly to the action of environmental factors. A greater genetically determinated variability within the $F_{1}$ hybrid group could not be expected either. On the other hand, interline differences were mainly of genetic origin, although eventually they might be a manifestation of the genotype $x$ environment interaction.

The growth curves of inbred and hybrid groups are shown in figures 4-7 and the parameters of the curves are summarized in tables 5-8. The shape parameter (n) and the $\mathrm{y}^{*} / \mathrm{A}$ ratio show a wide range of values for individual curves $(\mathrm{n}=-0.3$ to 0.8 and $\mathrm{y}^{*} / \mathrm{A}=0.279$ to 0.480$)$. The average values of different groups are within the range $\mathrm{n}=-0.100$ to 0.271 and $\mathrm{y} * / \mathrm{A}=0.347$ to 0.410 , demonstrating that the growth of chickens can generally be expressed by the Gompertz function $(y * / A=0.368)$. This function has been used to analyze turkey growth (Buffington et al., 1973).

A comparison of the course of growth and the shape of curves (parameters $n$, $\left.\mathrm{y}^{*} / \mathrm{A}\right)$ in cockerels of inbred strains reveals a similar trend in the Iowa and $\mathrm{C}$ lines (tabl. 5). Higher average shape parameter values and, therefore, higher values of the $y *$ / A ratio, characterize the curves of the $W$ and $M$ lines. However, it should be emphasized that the $\mathrm{W}$ and $\mathrm{M}$ lines differed significantly $(P<0.01)$ as to the time needed to reach the inflection point $\left(t^{*}=77,4\right.$ vs. 101,0 days) and, therefore, as to growth rate parameters $\left(\mathrm{k}, \mathrm{v}, \mathrm{v}^{*}\right)$. The post-inflection growth phase was first entered by the $\mathrm{C}$ line, followed by Iowa and $\mathrm{W}$, with a marked delay in the Minor cockerels. The order of lines in reaching the inflection point $\left(\mathrm{y}^{*}\right)$ was the same in regard to weight as the order of final weight (A) : I $<\mathrm{C}<\mathrm{W}<\mathrm{M}$. It should be noted in this connection that the correlation $r_{P}=0.14, r_{G}=0.39$ between $y^{*}$ and $A$ has also been demonstrated in mice (TIMON \& EISEN, 1969). Coefficients of correlation $\left(r_{p}\right)$ ranging from 0.57 to 0.89 were obtained in our laboratory in unselected fowl populations (White Leghorn, New Hampshire, Orpington). 


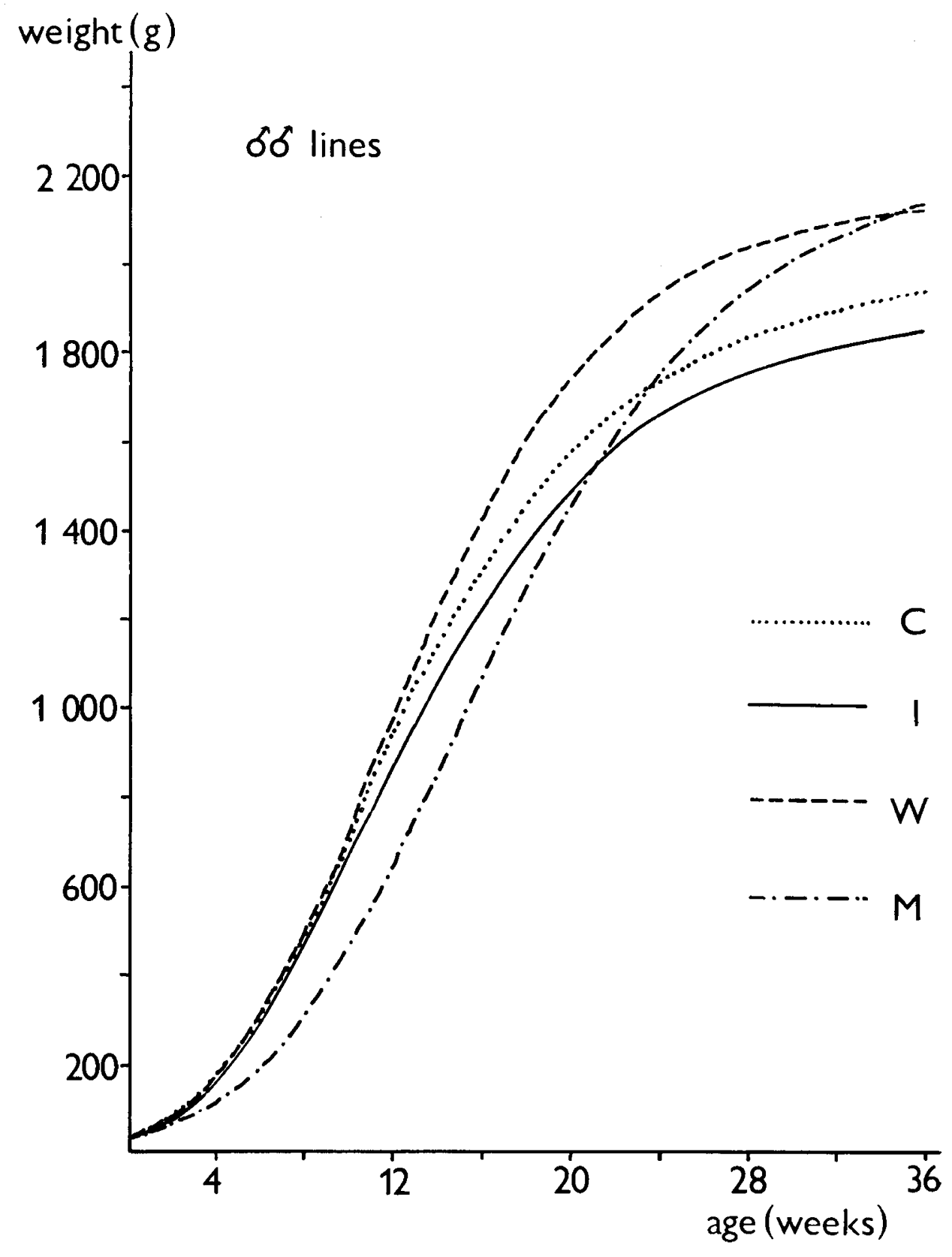

FIG. 4

Growth curves of cockerels of inbred lines.

Courbes de croissance des coqs de lignées consanguines. 


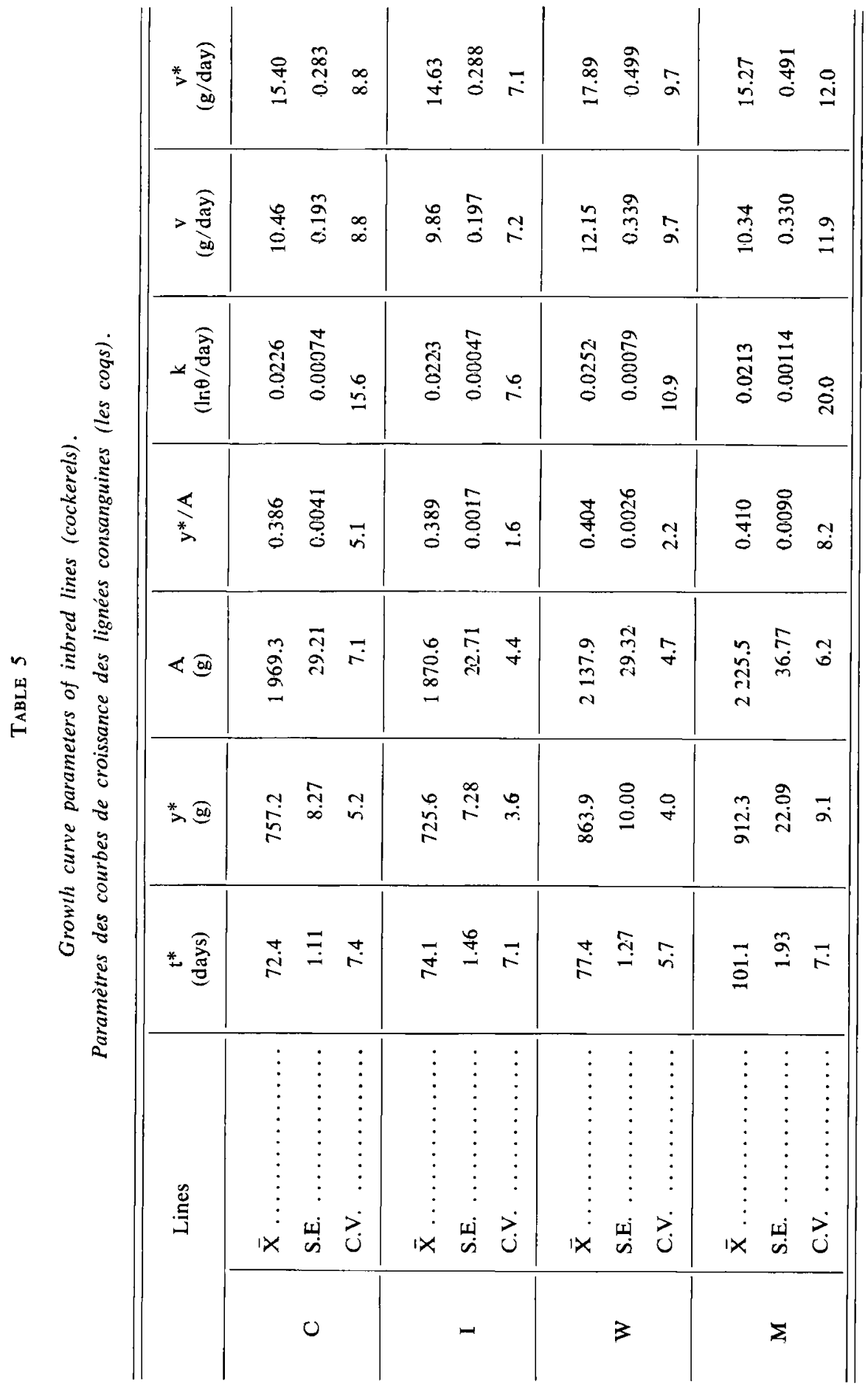


The pullets of inbred lines showed a pattern of intra- and inter-line differences similar to those of cockerels (tabl. 6). Higher $y^{*} / A$ ratio values were recorded in the $\mathrm{W}$ and $\mathrm{M}$ strains; minor pullets were also slower to reach the inflection point $\left(\mathrm{t}^{* *}\right)$. The highest growth rate parameters $\left(\mathrm{v}, \mathrm{v}^{*}\right)$, recorded in the $\mathrm{W}$ line, were associated with a comparatively late transition to the post-inflection phase.

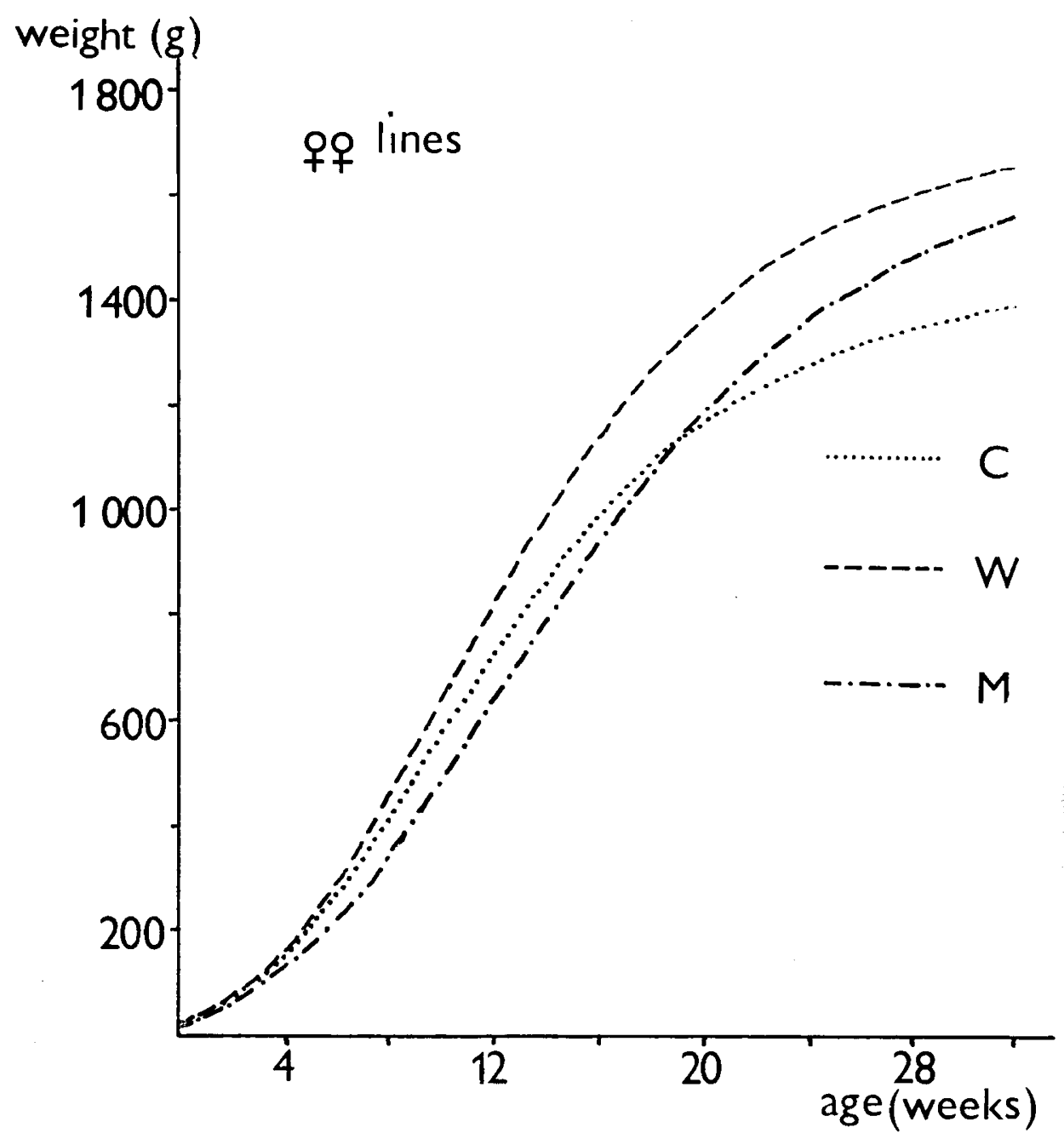

FIG. 5

Growth curves of pullets of inbred lines.

Courbes de croissance des poules de lignées consanguines. 


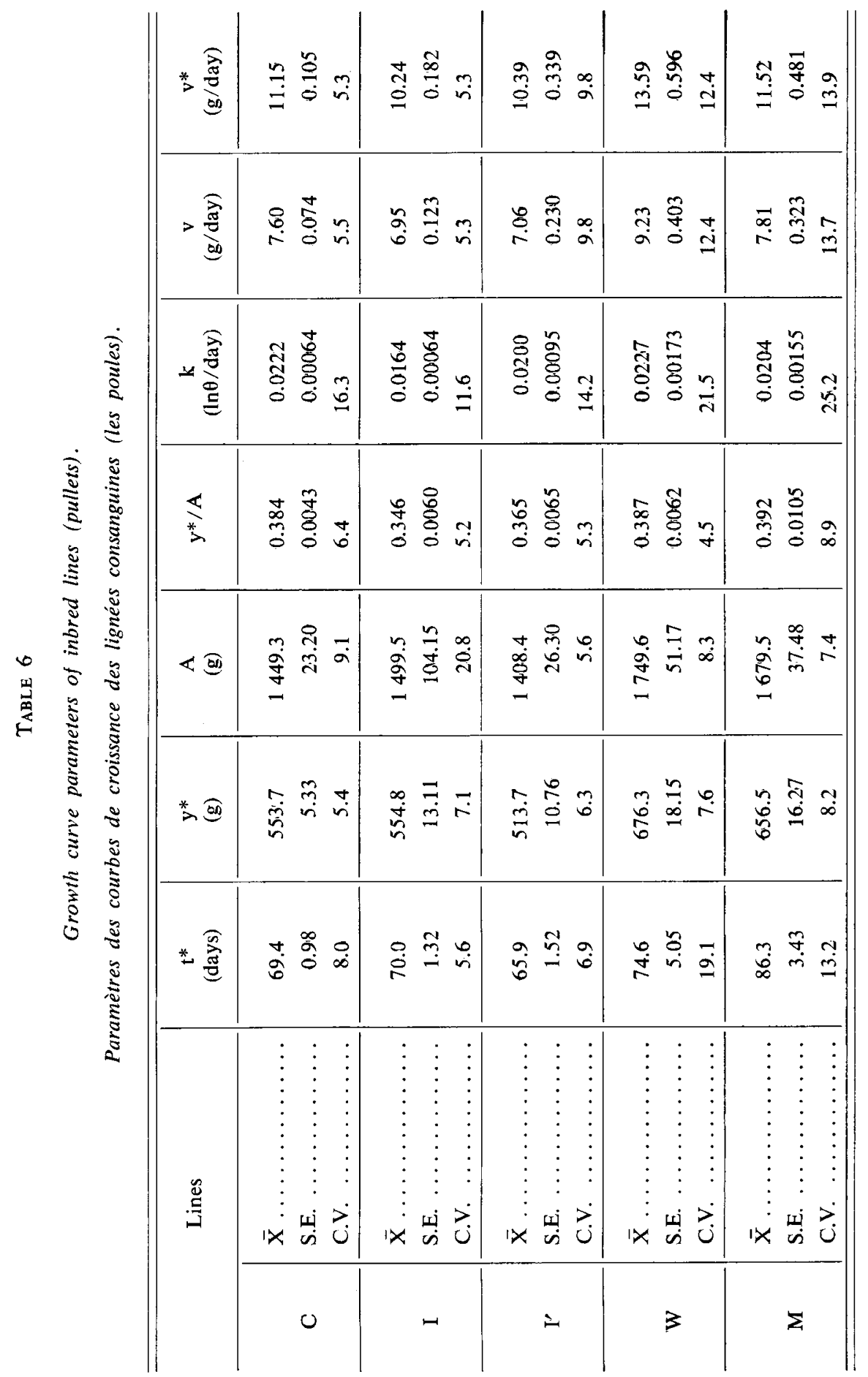




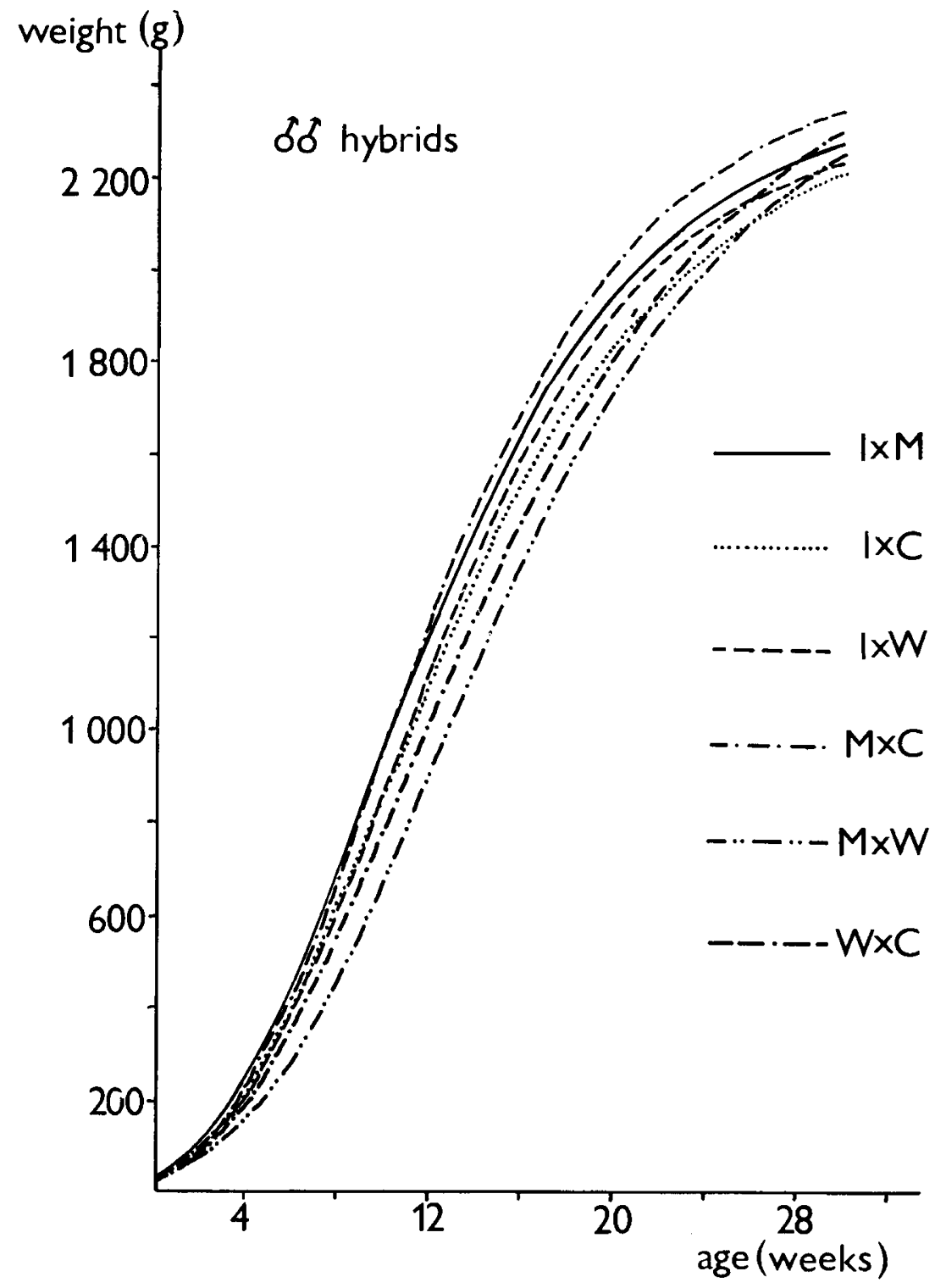

FIG. 6

Growth curves of $F_{1}$ cockerels - Courbes de croissance des coqs hybrides.

The course of the $F_{1}$ hybrid growth is shown in figures 6 and 7 and the curve parameters are presented in tables 7 and 8 . Due to the limited number of chickens, we could not evaluate differences in group variability. Nevertheless, it is obvious that in inbred lines and in hybrids of both sexes, the $\mathrm{k}$ parameter showed the highest coefficients of variability (C.V. $=6.6$ to 25.2 p. 100). A comparatively lower intra- 
group variability was noted in the $\mathrm{y}^{*}(\mathrm{C} . \mathrm{V} .=1.7$ to 9.1 p. 100) and $\mathrm{y} * / \mathrm{A}(\mathrm{C} . \mathrm{V} .=$ 0.0 to 9.2 p. 100) parameters.

Data on the analysis of variance of curve parameters are included in table 9. Taking the characteristics of the parental material $\left(F_{x}>99.9\right.$ p. 100) as a basis, it follows that the genetic differences between lines, and eventually between hybrid combinations, are an important source of the total variance. The highest inter-group variance was recorded for age and weight at inflection point $\left(t^{*}, y^{*}\right)$, higher values being obtained between inbred lines than between $F_{1}$ hybrids. The component determined by genotype was also comparatively high for average and maximal absolute growth rates $\left(\mathrm{v}, \mathrm{v}^{*}\right)$. The situation is similar for the variance of the asymptote of inbred lines. The low value in $F_{1}$ hybrids, particularly in pullets, can probably be ascribed to an inaccurate estimation of $\mathbf{A}$, since the genetic variance for maximal live weight $\left(\mathbf{A}^{\prime}\right)$ remained high (of $f 74.3$ p. 100 , \& $\& 54.2$ p. 100). The inter-group variance for the $\mathrm{y}^{* /}$ A ratio was comparatively low (22.6 to 31.3 p. 100).

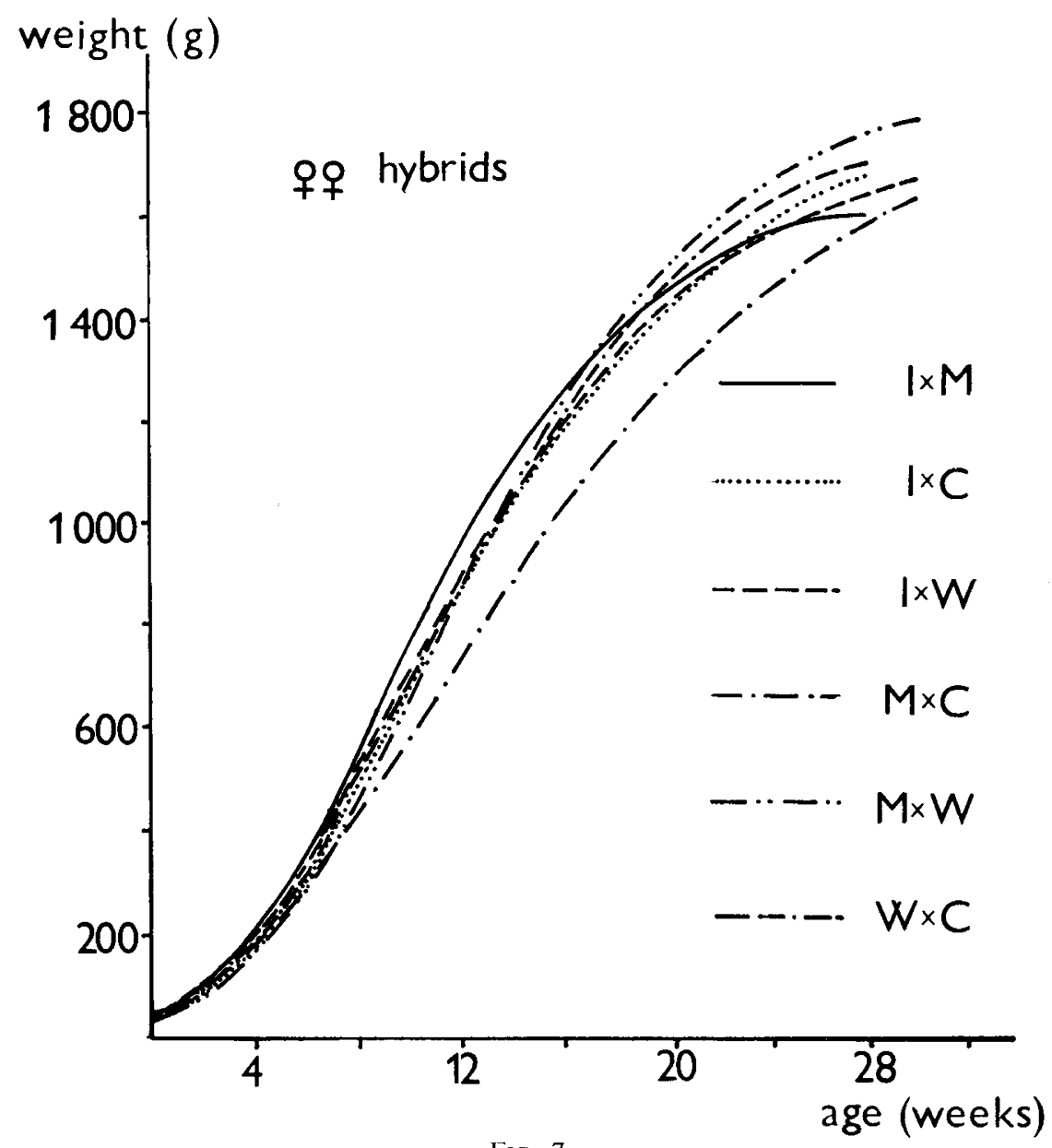

FIG. 7

Growth curves of $F_{1}$ pullets - Courbes de croissance des poules hybrides. 


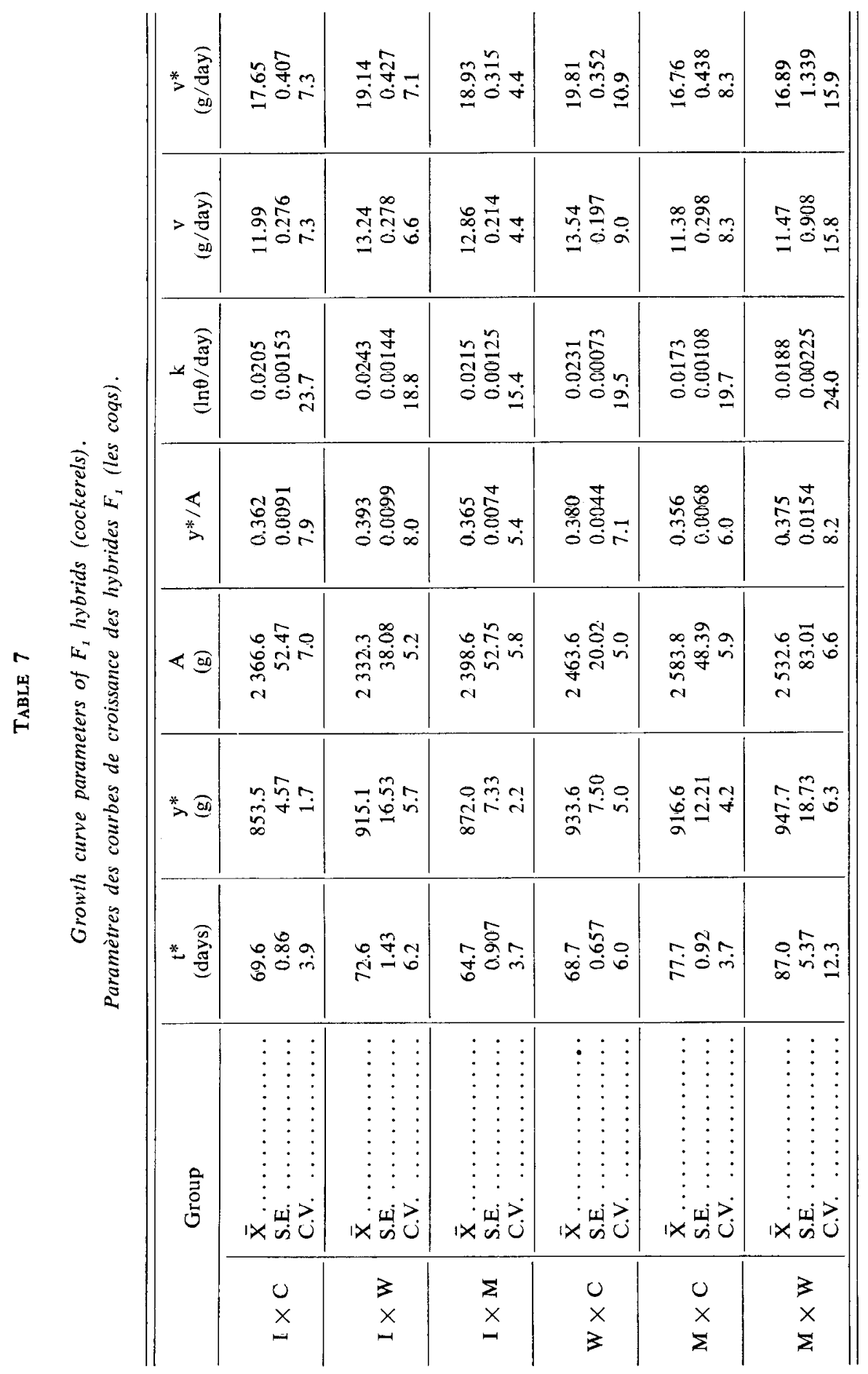




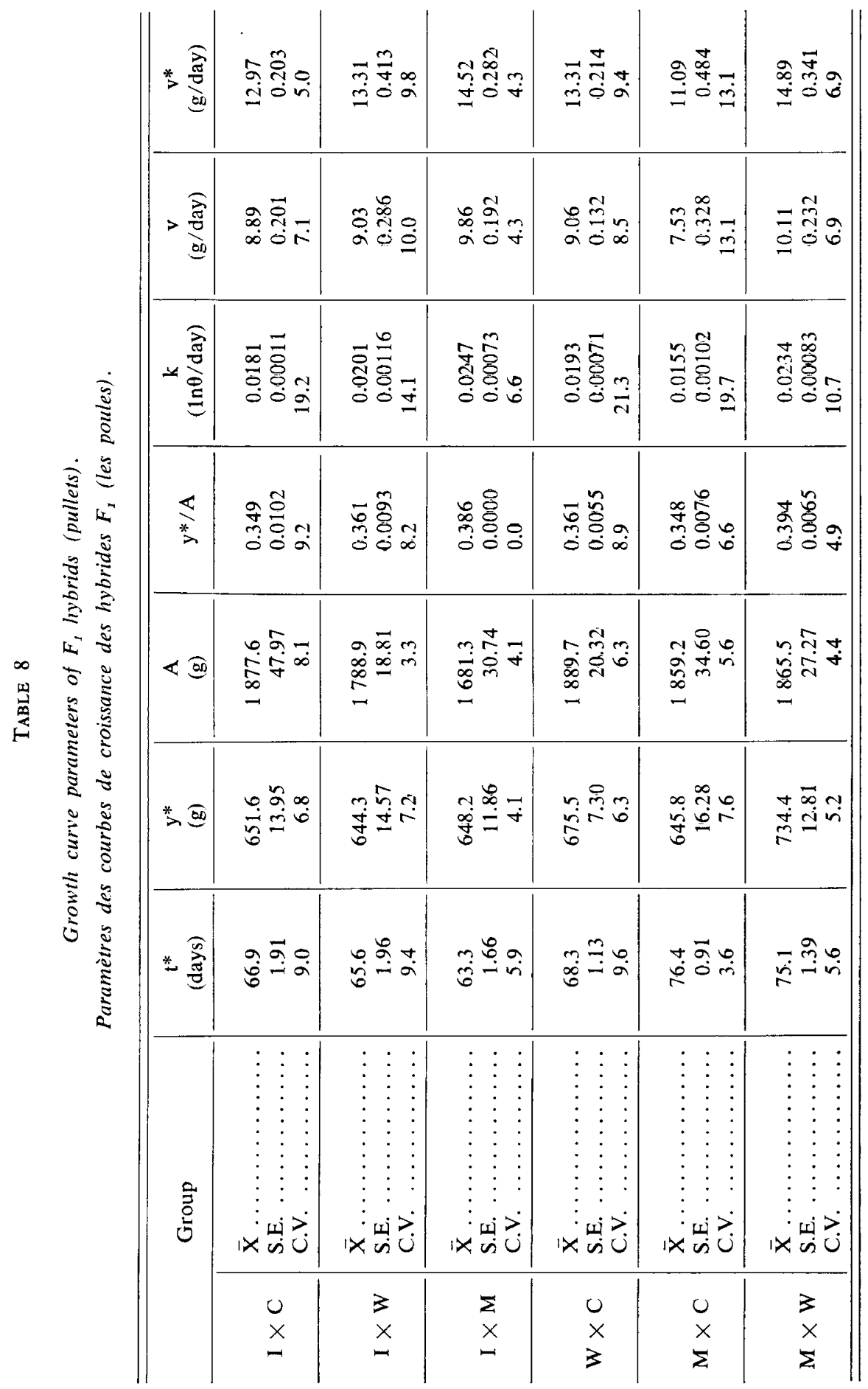




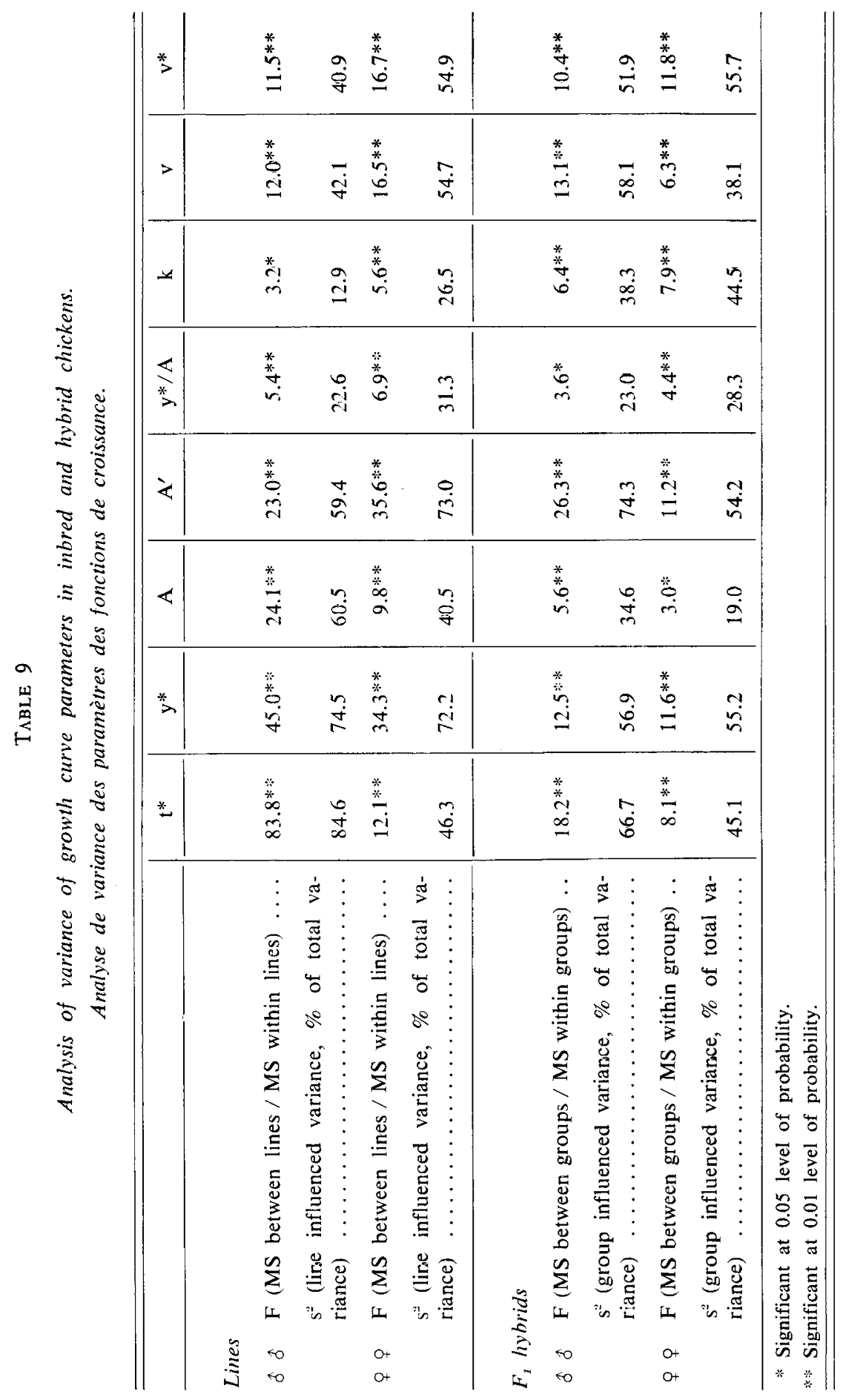


A comparison of hybrids with parental lines gave estimates of heterosis in individual growth curve parameters (tabl. 10 and 11). In our experiment comparing different inbred and hybrid groups, age at the inflection point of the curve occurred within a wide range (from 63.3 to 101.1 days) on an average, the hybrids showed some shifting towards an earlier inflection : cockerels -9.4 p. 100 , pullets -7.6 p. 100 (tabl. 10). Some hybrids were significantly more precocious $\left(t^{*}\right)$ than the earlier parental line (tabl. 11). This manifestation of heterosis depended on particular parental lines and hybrid combinations; a more detailed analysis of these effects would require a representation of all groups of reciprocal crosses. LAIRD \& How ARD (1967) found a shift to an earlier age at the inflection point in hybrids of inbred lines of mice.

In the growth analysis of chickens of commercial populations of egg and meat types, the parameter values for age at the inflection point were shifted to an earlier period. For instance, when the power function $y=a^{\mathrm{t}}{ }^{\mathrm{b}}$ was applied, it was found that growth rate (b) began to decrease at the age of 7-8 weeks (RoBERTs, 1964). In another analysis applying the logistic function, the maximal absolute growth rate of broiler chickens was estimated to occur at the age of 35.5 to 48.3 days at a live weight of 763 to $1261 \mathrm{~g}$ (LiLJEDAHL, 1970), although the author admitted that the weights were underestimated with respect to the growth capacity of the meat-type broiler population. This assessment agrees with the results of Wilson (1977) who applied the Gompertz function to the growth of meat-type chickens (Ross 1). The inflection point in cockerels was estimated to occur at 55 days of age at a live weight of about $2.0 \mathrm{kgs}$.

A comparison of hybrid weight at the inflection point reveals positive deviations from the mid-parent value (tabl. 10). In some cases the hybrids significantly exceeded the parent line with higher parameters (tabl. 11). The higher values of the asymptote for the majority of hybrid combinations, compared with pure lines, are a distortion due, to some extent, to inaccurate estimation. Nevertheless, the significant differences where $F_{1}$ exceeded the max. $\left(P_{1}, P_{2}\right)$ for the observed final weights in groups of males $\mathbf{I} \times \mathbf{C}, \mathbf{C} \times \mathbf{M}, \mathbf{M} \times \mathbf{C}$ and females $\mathbf{I} \times \mathbf{C}, \mathbf{M} \times \mathbf{W}$, suggest that manifestations of the heterosis effect are maintained up to maturity in some hybrid combinations. Taking into account the higher parameter values in hybrids, it is not surprising to find heterosis in average and maximal absolute growth rate $\left(\mathrm{v}, \mathrm{v}^{*}\right)$.

\section{Sex differences}

As expected, the cockerels showed significantly higher estimates (tabl. 5-8) for parameters immediately related to live weight and growth rate $\left(\mathrm{y}^{*}, \mathrm{~A}, \mathrm{v}, \mathrm{v}^{*}\right)$. Cockerels reached the inflection point $\left(t^{*}\right)$ later but the differences were small and in most cases statistically insignificant. A shift in the age parameter at the inflection point towards higher values in the male sex was also reported by LiLjEDAHL (1970). The values of the remaining curve parameters $(\mathrm{y} * / \mathrm{A}, \mathrm{k})$ were somewhat higher in cockerels but all these differences were insignificant. 


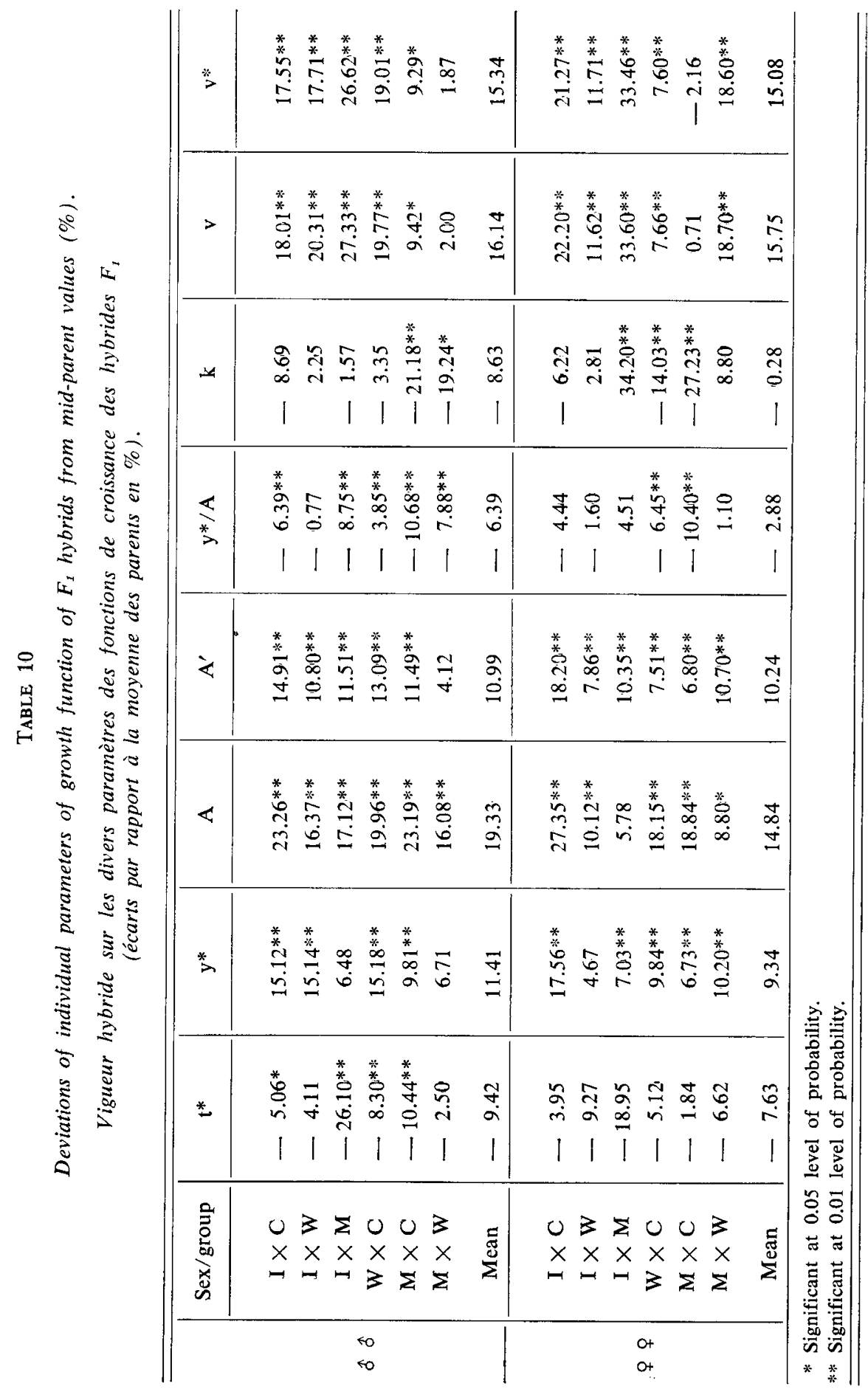


TABLE 11

Deviations of individual parameters of growth functions of $F_{1}$ hybrids from better parent.

Ecarts des divers paramètres des fonctions de croissance des hybrides $F_{1}$ par rapport au meilleur des parents.

\begin{tabular}{|c|c|c|c|c|c|c|c|}
\hline & Sex/group & $\begin{array}{c}\mathrm{t}^{*} \\
\text { (days) }\end{array}$ & $\begin{array}{l}y^{*} \\
(g)\end{array}$ & $\begin{array}{c}\mathrm{A} \\
(\mathrm{g})\end{array}$ & $\begin{array}{l}A^{\prime} \\
(g)\end{array}$ & $\begin{array}{c}\mathrm{V} \\
(\mathrm{g} / \text { day })\end{array}$ & $\begin{array}{c}v^{*} \\
(g / \text { day })\end{array}$ \\
\hline \multirow{6}{*}{$\delta \hat{\sigma}$} & $\mathrm{I} \times \mathrm{C}$ & $-2.88^{*}$ & $96.3 * *$ & $397.3 * *$ & $243.5 * *$ & $1.53 * *$ & $2.25 * *$ \\
\hline & $\mathbf{I} \times \mathbf{W}$ & -1.46 & $51.2 *$ & $194.4 * *$ & 73.2 & $1.09 *$ & 1.25 \\
\hline & $\mathbf{I} \times \mathbf{M}$ & $-9.36^{* *}$ & - & $173.1^{*}$ & $105.0^{*}$ & $2.52 * *$ & $3.66 * *$ \\
\hline & $\mathrm{W} \times \mathrm{C}$ & $-3.74^{* *}$ & $69.7^{* * *}$ & $325.7 * *$ & $169.2 * *$ & $1.39 * *$ & $1.92 * *$ \\
\hline & $\mathbf{M} \times \mathbf{C}$ & 一 & 4.3 & $358.3^{* *}$ & $153.6^{* *}$ & $0.92 *$ & $1.36^{*}$ \\
\hline & $\mathbf{M} \times \mathbf{W}$ & 一 & 35.4 & $307.1^{* *}$ & 68.2 & 一 & 一 \\
\hline \multirow{6}{*}{ 우 } & $\mathbf{I} \times \mathbf{C}$ & -3.07 & $97.9^{* *}$ & $378.1 * *$ & $198.1^{* * *}$ & $1.29 * *$ & $1.82 * *$ \\
\hline & $\mathbf{I} \times \mathbf{W}$ & -4.39 & 一 & 39.3 & - & - & 一 \\
\hline & $\mathbf{I} \times \mathbf{M}$ & -6.67 & - & 1.8 & 20.5 & $2.05 * *$ & $3.00^{* *}$ \\
\hline & $\mathrm{W} \times \mathrm{C}$ & -1.05 & - & $140.1^{*}$ & 一 & 一 & - \\
\hline & $\mathbf{M} \times \mathbf{C}$ & - & 一 & $179.7^{* *}$ & 10.1 & - & 一 \\
\hline & $\mathbf{M} \times \mathbf{W}$ & - & $58.1^{*}$ & 115.9 & $125.0 * *$ & 0.88 & 1.30 \\
\hline
\end{tabular}

* Significant at 0.05 level of probability.

** Significant at 0.01 level of probability.

Received December 12, 1982.

Accepted May 30, 1983.

\section{Acknowledgements}

We would like to thank the referees for their valuable criticism of this manuscript and for correcting our English. The authors wish to thank the scientific editor of G.S.E. and Mrs. DaIfuku for necessary revision of the final manuscript.

\section{References}

Brown J.E.H., Fitzhugh H.A., Cartwright T.C., 1976. A comparison of nonlinear models for describing weight-age relationships in cattle. J. Anim. Sci., 42, 810-818.

BUfFington D.E., JoRdan K.A., Boyo L.L., JUnNila W.A., 1973. Mathematical models of growth data of male and female Wrolstad White turkeys. Poult. Sci., 52, 1694-1700.

Clovgh M., Cock A.G., 1957. Variability of inbred and incross chicken. Nature, 179, 1030-1031.

Cock A.G., Morton J.R., 1963. Maternal and sex linked effects on size and conformation in domestic fowl. Heredity, 18, 337-350. 
Eisen E.J., Lang B.J., Legates J.E., 1969. Comparison of growth functions within and between lines of mice selected for large and small body weight. Theor. Appl. Genet., 39, 251-260.

Festing M.F.W., 1979. Inbred strains in biomedical research. The Mac Millan Press, LTD.

FITZHUGH H.A., 1976. Analysis of growth curves and strategies for altering their shape. J. Anim. Sci., 42, 1035-1051.

Kidwell J.F., Howard A., Laird A.K., 1969. The inheritance of growth and form in the mouse. II - The Gompertz growth equation. Growth, 33, 339-352.

LaIRD A.K., Howard A., 1967. Growth curves in inbred mice. Nature, 213, 786-788.

LILJEDAHL L.E., 1970. A study of the course of growth in broiler chickens. Acta Agric. Scand., 20, 249-256.

Morton J.R., 1973. Analysis of gene action in the control of body weight in the chicken. Heredity, 31, 165-180.

Richards F.J., 1959. A flexible growth function for empirical use. J. Exp. Bot., 10, 290-300.

Roberts C.W., 1964. Estimation of early growth rate in the chicken. Poult. Sci., 43, 238-252.

Rutledge J.J., Robison O.W., Eisen E.J., Legates J.E., 1972. Dynamics of genetic and maternal effects in mice. J. Anim. Sci., 35, 911-921.

Timon V.M., Eisen E.J., 1969. Comparison of growth curves of mice selected and unselected for postweaning gain. Theor. Appl. Genet., 39, 345-351.

Weber E., 1972. Grundriss der biologischen Statistik. Gustav Fischer, Jena.

Wilson B.J., 1980. Growth in birds for meat production. In : Lawrence T.L.J., Growth in animals, 265-272. Butterworths, London. 